The key to diagnosis in such circumstances seems to be radiological as $90 \%$ of this series of patients had the diagnosis correctly established after investigation. In this respect, the lateral decubitus film is particularly helpful.

The risk to life in acute abdominal pain is related to age, rising from well under $1 \%$ in the under $50 \mathrm{~s}$ to $2 \%$ in patients in their $60 \mathrm{~s}, 5 \%$ in those in their 70 s, and $7 \%$ in the over $80 \mathrm{~s}$. We thus support the comments of previous correspondents but suggest a wider conclusion. All elderly patients with acute abdominal pain must be assessed with particular care (both neoplastic and vascular causes being routinely considered). Otherwise, even the alert may be misled.

F T DE DOMBAL $S$ TELFER

St James's University Hospital,

Leeds LS9 7TF

1 de Dombal FT. The OMGE acute abdominal pain survey. Progress report 1982. Scand 7 Gastroenterol 1984;19 (suppl 95):28-40.

2 Fenyö G, Helsingen N, de Dombal FT, Holt PR, Telfer S. Acute abdominal pain in elderly patients. Data presented to 8 th world congress of gastroenterology, Sao Paulo, Brazil 1986. Dig Dis Sci 1987;10:142.

\section{Bone turnover and trabecular plate survival after artificial menopause}

SIR,-The measurement of bone matrix proteins in plasma or urine may answer Dr J Reeve's call for simple ways to identify perimenopausal women at risk of osteoporosis (26 September, p 757).

The report that combinations of serum alkaline phosphatase, urinary hydroxyproline, and urinary calcium have been shown to differentiate between fast and slow bone losers is exciting, but these measurements are not specific for bone turnover. ${ }^{1}$ Recent advances in bone matrix protein biochemistry may, however, offer ways of improving specificity and sensitivity. ${ }^{2}$

Osteocalcin (bone Gla-protein) is released from activated osteoblasts, and serum concentrations predict the histological bone profile in postmenopausal women. ${ }^{3}$ As yet there is not a corresponding marker of bone destruction, but estimations of urinary deoxypyridinoline may measure bone specific collagen breakdown. ${ }^{4}$ Preliminary work has shown that postmenopausal women may be classified according to the degree of bone formation measured by serum osteocalcin, suggesting fundamental differences in bone turnover between patients. ${ }^{3}$

Prospective clinical studies of these new measures are needed to determine whether identification of patients with high or low bone turnovers before the menopause will help to predict increased risk of developing osteoporosis.

PAUL W Thompson

Bone and Joint Research Unit,

The London Hospital Medical College,

London E1 2AD

1 Christiansen C, Riis BJ, Rodbro P. Prediction of rapid bone loss in postmenopausal women. Lancet 1987;i:1105-8.

2 Termine JD. Bone proteins. Bone 1987;4:15-6.

3 Brown JP, Delmas PD, Malaval L, Edouard C, Chapuy MC,

Menuier PJ. Serum bone Gla-protein: a specific marker for Menuier PJ. Serum bone Gla-protein: a specific marker for
bone formation in postmenopausal osteoporosis. Lancet bone formatio

4 Robins SP, Duncan A. Pyridium crosslinks of bone collagen and their location in peptides isolated from rat femur. Biochim Biophys Acta (in press)

\section{Is birth weight determined genetically?}

SIR,-We agree with Dr Roy Carr-Hill and colleagues (19 September, $p$ 687) that elucidating the role of genetics in determining birth weight poses considerable conceptual and methodological problems. We are puzzled, however, by certain aspects of their study.

Their basic hypothesis, which is not clearly stated, is presumably that if genetic factors are important then a close correlation will be seen between the birth weights of mother-child pairs (who share $50 \%$ of their genetic material) once confounding environmental factors are taken into account. The confounders considered by $\mathrm{D}$ Carr-Hill and coworkers were maternal height, gestational age, and proteinuric pre-eclampsia with fetal sex, maternal age, and parity controlled for essentially by selection.

The correlation between generations observed for birth weight was $0 \cdot 215$, which reduces to $0 \cdot 154$ after adjustment. Similar reductions are observed for both the slightly higher mother-daughter correlations and the slightly lower mother-son values. From the low adjusted correlations $D$ Carr-Hill and colleagues conclude that genetic factors have only a minor influence on birth weight.

We have two main concerns about this study. Firstly, it is not clear that the factors taken into account are solely environmental. Specifically, it is inappropriate to control for maternal height in this context as it must at least in part reflect fetal genetic composition. Secondly, notwithstanding this potential overcontrolling, the overall effect of the adjustment for confounders is very small, particularly in comparison with sampling error. The emphasis in the paper's abstract on the adjusted correlations therefore masks the fact that the raw correlations are much lower than those found in other studies, the reasons for which are not at all clear from the paper.

In conclusion, though we agree with $\mathrm{Dr}$ Carr-Hill and coworkers about the need for due consideration to be given to confounding effects, their efforts have been severely compromised by overcontrol, a recurrent problem in epidemiological research.

I M HARVEY

T J PETERS

R R WEST

Departments of Epidemiology and Community Medicine

and Medical Computing and Statistics,

University of Wales College of Medicine,

Cardiff CF4 4XN

\section{Commercialisation of medical education}

SIR,-Professor M D Vickers rightly raises an important issue (26 September, p 785), which had also occurred to me.

I attended the recent British fournal of Hospital Medicine's conference on intensive care with mixed feelings. On the one hand, it was an opportunity to participate, free and with little effort, in a very attractive, though exceedingly expensive, international scientific event and meet some of my distinguished colleagues and friends from abroad On the other hand, as Professor Vickers points out, the meeting had a distasteful commercial basis, which I personally found especially disturbing as the Federation of Societies of Intensive and Critical Care Medicine, of which I am president, is desperately short of funds. The organisers also made certain unjustified claims and unacceptable announcements. In general, at least part of the profit from scientific meetings is returned to the relevant scientific body and is a valuable source of funds. I was informed that the primary purpose of this meeting was not direct profit but the promotion of the journal itself, indirect profit; certainly an unusual and doubly rewarding way of enhancing the subscription list of what is claimed to be an ethical scientific journal.
While I enjoyed the symposium I would, on reflection, not attend such a meeting again. Incidentally, I can assure Professor Vickers that I personally received no fee and claimed no expenses. One of my colleagues believed that the register of participants showed that about half were nurses, an interesting observation. Can British nurses get funds more easily than doctors?

The commercial exploitation of communication in medicine and science, indeed of learning in general, is not new. But while few contributors become rich through books and journals literature is indispensable, and publishers provide a service we cannot in a relationship normally as close to symbiosis as we can hope for. Unfortunately there are already too many interested commercial parties in the massive and highly lucrative international business of conference organisation, and this event has shown we can lose our legitimate share of such profit. The United States has a well established, and invaluable, system of credits, which, inter alia, demands the fulfilment of certain criteria for official recognition of scientific meetings. Should we, and other developed countries, consider such a system for our own protection? It could prove a powerful defence weapon in the face of a perceived threat to our legitimate professional interests. What about an ad hoc committee from the specialty of anaesthesia to begin with?

National Heart Hospital

Alan Gilston

London WI

SIR,-I would like to rise to the bait put out by my friend Professor M D Vickers in his letter on the commercialisation of medical education (26 September, $\mathrm{p}$ 985).

Parenthetically, readers may need to be reminded that Professor Vickers is a coauthor of more than one educational textbook, written no doubt with the highest ideals, but with commercial gain as a secondary and unfortunate byproduct.

With respect to the main points in his letter, it might be considered unfortunate that revenue escapes from the National Health Service. On the other hand, as a consumer of the product on three occasions, and not as a speaker, I would say that I buy a product only at a price that I think desirable. This must go on for the several hundred other people who have attended these meetings. Perhaps what the association and faculty might learn from the situation is that a good programme, with appropriate speakers on a subject of wide interest, is more saleable than some (but not all) of the stodgy programmes put out by the said organisations. Perhaps they might also consider whether the "purchasers" of postgraduate education always want to hear the same people (often academics and non-clinical) talking incessantly, often on clinical but disparate subjects, when they lack clinical credibility?

In a country where free market forces operate a product that offers the best value for money will always be purchased by the consumer, whether that product is a meeting or textbook. If any profit may be considered to be commercial is there any difference between that profit going to a publisher or to an individual author?

Royal Surrey County Hospital,

JULian M Leigh Surrey GU2 5 XX

\section{Reducing late abortions}

SIR,-The Birth Control Trust held a conference recently, which was reported on in Medical News (26 September, p 787). Unfortunately, the information in the first paragraph is seriously in error. Only $0.8 \%$ of all abortions performed for women

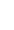

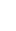
. 